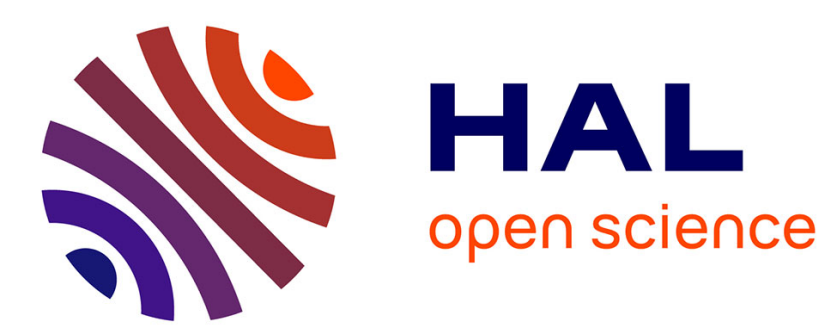

\title{
Predictive Factors of HIV Status Disclosure to Sex Partner in Pregnant Women in Cayenne, French Guiana
}

Narcisse Elenga, Matthieu Hanf, Mathieu Nacher

\section{To cite this version:}

Narcisse Elenga, Matthieu Hanf, Mathieu Nacher. Predictive Factors of HIV Status Disclosure to Sex Partner in Pregnant Women in Cayenne, French Guiana. Epidemiol, 2012, 2 (2), pp.1000116. 10.4172/2161-1165.1000116 . inserm-00915113

\section{HAL Id: inserm-00915113 https://www.hal.inserm.fr/inserm-00915113}

Submitted on 6 Dec 2013

HAL is a multi-disciplinary open access archive for the deposit and dissemination of scientific research documents, whether they are published or not. The documents may come from teaching and research institutions in France or abroad, or from public or private research centers.
L'archive ouverte pluridisciplinaire HAL, est destinée au dépôt et à la diffusion de documents scientifiques de niveau recherche, publiés ou non, émanant des établissements d'enseignement et de recherche français ou étrangers, des laboratoires publics ou privés. 


\title{
Predictive Factors of HIV Status Disclosure to Sex Partner in Pregnant Women in Cayenne, French Guiana
}

\author{
Elenga Narcisse ${ }^{1 *}$, Hanf Matthieu ${ }^{2}$ and Nacher Mathieu ${ }^{3,4}$ \\ ${ }^{1}$ Department of Pediatrics, Centre Hospitalier de Cayenne "Andree Rosemon" Street Flamboyants BP 6006, 97306 Cayenne Cedex, French Guiana \\ ${ }^{2}$ Clinical Investigation Center, Clinical Epidemiology (CIC-EC) Antilles-Guyane, BP 6006, Rue Flamboyants, 97306 Cayenne Cedex, French Guiana \\ ${ }^{3}$ Regional Coordination HIV (COREVIH) Guyana Street Flamboyants BP 6006, Cedex 97306 Cayenne, French Guiana \\ ${ }^{4}$ University Antilles-Guyane, French Guiana
}

\begin{abstract}
Background: The aim of this study was to identify the predictive factors of HIV disclosure to the sex partner in HIV pregnant women in Cayenne (French Guiana).

Methods: A case control study was conducted including all deliveries in Cayenne from 2003 to 2010. For each case, a standardized questionnaire including epidemiological, clinical, and biological data was administered. Thirty-four women in the first group and 95 in the control group were included in the study.

Results: The logistic regression showed that the variables that independently predicted HIV disclosure to the sex partner were the existence of a profession $(O R=5.62, I C 95 \%=1.3-24.26, p=0.021)$, disclosure to the doctor $(O R=12.65$, IC95\% $=2.87-55.8, p<0.001)$, the negative representations of HIV $(\mathrm{OR}=5.99, \mathrm{IC} 95 \%=1.17-30.69, \mathrm{p}=0.032)$. The partner's HIV status was also linked to the outcome $(\mathrm{OR}=0.01, \mathrm{IC} 95 \%=0.001-0.07, p<0.001)$.
\end{abstract}

Conclusion: These predictive factors should be considered in positive prevention programs and prevention of mother to child transmission.

Keywords: Human immunodeficiency virus infection; Pregnant women; HIV disclosure to the sex partner; French Guiana

\section{Introduction}

French Guiana is a French overseas territory of 229, 000 inhabitants neighboring Brazil and Suriname in the Amazonian region. This region is characterized by a high HIV prevalence and a high birth rate, notably in the most vulnerable populations. The transmission of HIV occurs mostly through heterosexual sex and women represent half of the HIV cohort in Cayenne [1-5]. A recent study suggested that a significant proportion of new infections may have been transmitted by patients who knew their diagnosis and thus emphasised the importance of "positive prevention" [6]. Immigrants account for $40.5 \%$ of the adult population of Cayenne, which had 58,004 inhabitants [7]. Eighty percent of patients are foreigners and they are often diagnosed at a later stage than French patients [8]. When diagnosed there is also a high rate of follow up interruption [9]. Prevention is complicated by the fact that a number of persons are illiterate [10] or do not understand the language. The health priorities of migrants are often overridden by daily struggles to obtain food, shelter, papers. In $2009,1.3 \%$ of pregnant women were infected with HIV, and in certain communities the HIV prevalence reached $4 \%$ (Rapport COREVIH Guyane 2009), which, according to UNAIDS, corresponds to a generalized epidemic. In Cayenne, the vertical transmission rate of HIV was $3 \%$, which is well beyond the transmission rate in metropolitan France. HIVpositive pregnant women often do not disclose their serostatus to their partners, family and friends, creating potential barriers to preventing sexual transmission to partners and mother-to-child transmission through breastfeeding [11-14]. In some past studies, the main risk factors for non-disclosure of serostatus to their sexual partners were: being nulliparous or unmarried, fear, regarding the spread of the information, stigmatization and deterioration in the relationship with the spouse [15], fear of abandonment; fear of relationship break-up and fear of stigma [16], fear of stigma and divorce [14], fear of stigma and discrimination [17].
A recent study of sociodemographic predictive factors of insufficient antiretroviral treatment in HIV-infected pregnant women in Cayenne showed that $70 \%$ of women had not disclosed their HIV status to the father of their child [18]. Another study in French Guiana showed lower proportion of non disclosure (16\%) possibly reflecting the particular vulnerability of pregnant women [19]. Although there was no significant link between disclosure and insufficient treatment, most programmes of mother to child HIV transmission prevention advice women to disclose the result of their test to the partner and to incite the partner to get tested. Studies have investigated disclosure, when it occurs, the partner's reactions, and the repercussions on the couple's life and condom use [20,21]. Given the staggering proportion of women failing to reveal their HIV status, the present study aimed to identify predictive factors of HIV disclosure to the sex partner in pregnant women in Cayenne, French Guiana.

\section{Methods}

\section{Study population}

The study concerned HIV-infected pregnant women having delivered at Cayenne General Hospital between 2003 and 2010. The total number of HIV-infected pregnant women delivering in Cayenne Hospital from 2003 to 2010 was 280.

*Corresponding author: Narcisse Elenga, Department of Pediatrics, Centre Hospitalier de Cayenne "Andree Rosemon" Street Flamboyants BP 6006, Cedex 97306 Cayenne, French Guiana, E-mail: elengafr@yahoo.fr

Received June 11, 2012; Accepted July 25, 2012; Published July 27, 2012

Citation: Narcisse E, Matthieu H, Mathieu N (2012) Predictive Factors of HIV Status Disclosure to Sex Partner in Pregnant Women in Cayenne, French Guiana. Epidemiol 2:116. doi:10.4172/2161-1165.1000116

Copyright: (C) 2012 Narcisse E, et al. This is an open-access article distributed under the terms of the Creative Commons Attribution License, which permits unrestricted use, distribution, and reproduction in any medium, provided the original author and source are credited. 


\section{Type of study}

The study was an exploratory matched case control study. Cases were HIV-infected mothers having delivered in Cayenne General Hospital between 2003 and 2010 and disclosed their HIV status to their sexual partner. Controls were mothers not having revealed their HIV status to their sex partner. Women having delivered at home in Cayenne or during transport were also included if they fitted the inclusion criteria. The status of the child was determined, depending on the child's age, either using viral load or using serology after 24 months of age. A child was considered as not infected if he had either two negative viral loads or a negative serology.

\section{Exclusion criteria}

Were excluded from this study, all mothers having refused to participate in the study, or when the children's final HIV status was undetermined or unknown.

\section{Identification of cases}

The outpatient department centralizes the follow-up of HIVpositive mothers, and the pediatric outpatient department centralizes the follow-up of children born from HIV-positive mothers. To identify cases according to the above inclusion criteria, the list of mothers having delivered at the Cayenne Hospital was established according to their children followed in pediatrics. The perinatal registry of the maternity ward allowed to verify the place of delivery and the identity of the mother. The eNADIS computerized HIV patient file [22] allowed us to collect maternal data and to cross-check data from other sources. Altogether, there were 36 eligible cases but one refused to participate and was thus excluded. Among these women, two were excluded because they refused to participate and denied having a HIV infection.

\section{Data collection}

Strategy: In the absence of centralized information on both mothers and children, data from different sources were gathered to be as thorough as possible and to cross-check information.

Identification of controls: All mothers having agreed to participate in the study and their children were followed. The HIV status of all participants was known during the pregnancy for twothirds of women and during delivery for one third. The present study was conducted by a paediatrician who followed up the children born from the participating women. It was more logical to start by compiling the list of infected women from the list of children born from an HIVinfected mother, in order to invite them to participate. Subsequently, additional data sources were used (i.e., the computerized patient files eNADIS ${ }^{\star}$ (Fedialis Medica, France), pregnancy registry). Through the use of multiple sources, an exhaustive list of all deliveries of HIVpositive women at Cayenne hospital was made. Incomplete files were excluded. From this list, women having disclosed their HIV status to their sexual partner were randomly sampled in order to obtain three controls per case matched by year of delivery. When the number of controls in a given year was not sufficient, the control was taken from the year following the delivery of the case.

Information on cases and controls: Once cases and controls were identified, available information was collected from the eNADIS file, the paediatric files, the blood bank, and obstetrical files.

Structured questionnaire: All eligible patients were then invited to the outpatient clinic to answer a structured questionnaire delivered by the pediatrician, the paediatric nurse, and the public health mediator of the department of paediatrics. Theses individual interviews were conducted from March to May 2010.

Data collection: A structured data collection form compiled all elements susceptible to influence access to care, HIV status disclosure and treatment. Maternal data on sociodemographic factors (residence, age, nationality, duration of residence in French Guiana, education level, languages spoken, possession of health insurance and residence permit, marital status, partner information, number of children, number of persons in the home, income, profession, transport used and distance from the hospital, and religion), the HIV infection (diagnosis date, knowledge of the father's status, disclosure of HIV status to the father, CD4 count, and treatment history), obstetrical factors (history, number of HIV positive pregnancies, parity, gravidity, desired pregnancy, planned pregnancy, number of prenatal consultations, follow-up location, quality of follow-up, alcohol use, tobacco use, drug use during pregnancy, breastfeeding, and difficulties to get milk powder), and factors such as disclosure to the family, the perception of others, representations on HIV/AIDS, knowledge of HIV transmission, and condom use. The interviews were conducted by trained professionals. After the training a guidebook for the surveyor was given. The questionnaire was pretested to evaluate its clarity. Before interviewing, each patient's information was given about the purpose of the study and the patient's right to refuse. The data collection forms used anonymous eNADIS numbers as patient ID. The database was notified to the National committee of computing and liberties.

\section{Data analysis}

Data were entered into Microsoft Excel 2007 and analyzed using R.2.10.0 (R project, CRAN R 2.10.0 version 2010) statistical software. After a descriptive analysis, some variables were categorized according to their distribution, the literature, or the study objectives. Matched bivariate analysis then studied covariates and their relation to the outcome measure by a crude odds ratio and its confidence interval. The covariates that were associated with the outcome $(\mathrm{p}<0.2)$ were then included in a multivariate conditional logistic regression model. The initial model included 10 variables (Education level, mode of transport, profession, Information and sharing of HIV status with close ones, use of condoms, desired pregnancy, disclosure to doctor, negative representations of HIV, partner's HIV status and HIV related diseases during pregnancy) and no interaction term. The most parsimonious model was obtained using the likelihood ratio test. An automated stepwise ascending and backward technique based on the AIC was also used. Finally, the adequation between the data and the model was tested.

\section{Results}

The study concerned 34 cases and 95 controls. The results are presented in table 1.

The median age of cases and controls was 31 years, with the majority of 26-35 years (50\% of cases and $54 \%$ of controls). Most women were of foreign origin ( $76 \%$ of cases and $90 \%$ of controls) with $38 \%$ Haitian in cases and $55 \%$ in controls. Most women had unprotected sex $(50 \%$ in cases, $83 \%$ in controls).

The distribution of cases and controls according to age, country of birth, education level, marital status, residence permit and housing was identical. For the women whose professional activity was available, 84 $\%$ had no steady job ( $74 \%$ of cases against $93 \%$ of controls). Only $24 \%$ of cases and $36 \%$ of controls of foreign origin did not have a residence permit. 
Citation: Narcisse E, Matthieu H, Mathieu N (2012) Predictive Factors of HIV Status Disclosure to Sex Partner in Pregnant Women in Cayenne, French Guiana. Epidemiol 2:116. doi:10.4172/2161-1165.1000116

\begin{tabular}{|c|c|c|c|c|c|c|}
\hline \multirow{2}{*}{ Variables } & \multirow{2}{*}{ Cases (\%) } & \multirow{2}{*}{ Controls (\%) } & \multicolumn{2}{|l|}{ Bivariate analysis } & \multicolumn{2}{|l|}{ Multivariate analysis } \\
\hline & & & Crude OR $(95 \% \mathrm{Cl})$ & $\mathbf{p}$ & Adjusted OR (95\% Cl) & $\mathbf{p}$ \\
\hline \multicolumn{7}{|c|}{ Demographic characteristics } \\
\hline \multicolumn{7}{|c|}{ Mother's age at the beginning of the pregnancy } \\
\hline$<26$ years & $6(18)$ & $22(23)$ & 1 & & - & - \\
\hline $26-35$ years & $17(50)$ & $51(54)$ & $1.22(0.42-3.52)$ & 0.710 & - & - \\
\hline$\geq 35$ years & $11(32)$ & $22(23)$ & $1.83(0.58-5.83)$ & 0.360 & - & - \\
\hline \multicolumn{7}{|l|}{ Country of birth } \\
\hline Other & $13(38)$ & $33(35)$ & 1 & & - & - \\
\hline Guiana/France & $8(24)$ & $10(10)$ & $2.02(0.66-6.28)$ & 0.220 & - & - \\
\hline Haiti & $13(38)$ & $52(55)$ & $0.63(0.26-1.54)$ & 0.310 & - & - \\
\hline \multicolumn{7}{|l|}{ Education level } \\
\hline Never schooled & $7(21)$ & $28(29)$ & 1 & & - & - \\
\hline Schooled & $27(79)$ & $67(71)$ & $1.61(0.63-4.13)$ & 0.320 & - & - \\
\hline \multicolumn{7}{|l|}{ Matrimonial status } \\
\hline Single & $12(35)$ & $48(51)$ & 1 & & - & - \\
\hline Couple & $22(65)$ & $47(49)$ & $1.87(0.83-4.21)$ & 0.120 & - & - \\
\hline \multicolumn{7}{|c|}{ Administrative status of foreigners } \\
\hline No residence permit & $6(24)$ & $31(36)$ & 1 & & - & - \\
\hline Residence permit & $19(76)$ & $54(64)$ & $1.82(0.66-5.03)$ & 0.240 & - & - \\
\hline \multicolumn{7}{|l|}{ Housing } \\
\hline House/appartment & $29(85)$ & $86(91)$ & 1 & & - & - \\
\hline In someone's house & $5(15)$ & $9(9)$ & $1.65(0.51-5.32)$ & 0.400 & - & - \\
\hline \multicolumn{7}{|c|}{ Socio-economic characteristics } \\
\hline \multicolumn{7}{|l|}{ Type of health insurrance } \\
\hline AME & $5(15)$ & $29(33)$ & 1 & & - & - \\
\hline CMU & $19(56)$ & $23(26)$ & $4.79(1.55-14.79)$ & 0.006 & - & - \\
\hline ALD & $10(29)$ & $37(41)$ & $1.57(0.48-5.09)$ & 0.460 & - & - \\
\hline \multicolumn{7}{|l|}{ Profession } \\
\hline No & $25(74)$ & $88(93)$ & 1 & & 1 & \\
\hline Yes & $9(26)$ & $7(7)$ & $4.53(1.53-13.37)$ & 0.006 & $5.62(1.30-24.26)$ & 0.020 \\
\hline \multicolumn{7}{|c|}{ Number of children to care for } \\
\hline$\leq 1$ child & $5(15)$ & $12(13)$ & 1 & & - & - \\
\hline 2-6 children & $6(17)$ & $38(40)$ & $0.38(0.1-1.47)$ & 0.160 & - & - \\
\hline$\geq 6$ children & $23(68)$ & $45(47)$ & $1.23(0.39-3.9)$ & 0.730 & - & - \\
\hline Mode of transport & & & & & & \\
\hline Other modes & $20(59)$ & $82(86)$ & 1 & & - & - \\
\hline Private car & $14(41)$ & $13(14)$ & $4.42(1.8-10.85)$ & 0.001 & - & - \\
\hline Disclosure to the Doctor & & & & & & \\
\hline No & $22(65)$ & $90(95)$ & 1 & & 1 & \\
\hline Yes & $12(35)$ & $5(5)$ & $9.82(3.13-30.78)$ & $<0.001$ & $12.65(2.87-55.8)$ & $<0.001$ \\
\hline Desired pregnancy & & & & & & \\
\hline No & $18(53)$ & $80(84)$ & 1 & & - & - \\
\hline Yes & $16(47)$ & $15(16)$ & $4.74(1.99-11.32)$ & $<0.001$ & - & - \\
\hline Use of condoms & & & & & & \\
\hline No & $17(50)$ & $79(83)$ & 1 & & - & - \\
\hline Yes & $17(50)$ & $16(17)$ & $4.94(2.09-11.68)$ & $<0.001$ & - & - \\
\hline Partner's HIV status & & & & & & \\
\hline Infected & $16(47)$ & $1(1)$ & 1 & & 1 & \\
\hline No infected & $18(53)$ & $94(99)$ & $0.01(0.005-0.1)$ & $<0.001$ & $0.01(0.001-0.07)$ & $<0.001$ \\
\hline Additional income & & & & & & \\
\hline No & $5(15)$ & $17(18)$ & 1 & & - & - \\
\hline Yes & $29(85)$ & $78(82)$ & $1.26(0.43-3.74)$ & 0.670 & - & - \\
\hline Benefitted from food parc & & & & & & \\
\hline No & $32(94)$ & $88(93)$ & 1 & & - & - \\
\hline Yes & $2(6)$ & $7(7)$ & $0.79(0.16-3.98)$ & 0.770 & - & - \\
\hline Perceptions towards HIV & & & & & & \\
\hline Negative image to others & & & & & & \\
\hline Absence & $4(12)$ & $4(4)$ & 1 & & - & - \\
\hline Presence & $30(88)$ & $91(96)$ & $0.33(0.08-1.4)$ & $0.130^{\star *}$ & - & - \\
\hline
\end{tabular}


Citation: Narcisse E, Matthieu H, Mathieu N (2012) Predictive Factors of HIV Status Disclosure to Sex Partner in Pregnant Women in Cayenne, French Guiana. Epidemiol 2:116. doi:10.4172/2161-1165.1000116

Page 4 of 6

\begin{tabular}{|c|c|c|c|c|c|c|}
\hline \multicolumn{7}{|c|}{ HIV gives a negative representations of HIV } \\
\hline Absence & $7(21)$ & $9(9)$ & 1 & & 1 & \\
\hline Presence & $27(79)$ & $86(91)$ & $6.48(1.99-21.08)$ & $0.002^{\star \star *}$ & $5.99(1.17-30.69)$ & 0.032 \\
\hline \multicolumn{7}{|c|}{ Alcohol or tobacco use during pregnancy } \\
\hline No & $29(85)$ & $77(81)$ & 1 & & - & - \\
\hline Yes & $5(15)$ & $18(19)$ & $0.16(0.02-1.27)$ & 0.084 & - & - \\
\hline \multicolumn{7}{|c|}{ Marijuana, crack or cocaine use } \\
\hline No & $29(85)$ & $89(94)$ & 1 & & - & - \\
\hline Yes & $5(15)$ & $6(6)$ & $0.48(0.1-2.27)$ & 0.350 & - & - \\
\hline \multicolumn{7}{|c|}{ Faiths and attitudes towards the HIV } \\
\hline \multicolumn{7}{|c|}{ Practice of religion } \\
\hline No & $4(15)$ & $11(12)$ & 1 & & - & - \\
\hline Yes & $30(85)$ & $84(88)$ & $0.95(0.28-3.21)$ & 0.930 & - & - \\
\hline \multicolumn{7}{|c|}{ Type of religion practiced } \\
\hline Catholic & $11(37)$ & $32(38)$ & 1 & & - & - \\
\hline Evangelical & $19(63)$ & $52(62)$ & $1.06(0.45-2.52)$ & 0.890 & - & - \\
\hline \multicolumn{7}{|c|}{ Use of traditional healer } \\
\hline No & $29(85)$ & $82(86)$ & 1 & & - & - \\
\hline Yes & $5(15)$ & $13(14)$ & $1.06(0.45-2.52)$ & 0.900 & - & - \\
\hline \multicolumn{7}{|c|}{ The woman has a new partner } \\
\hline No & $33(97)$ & $76(80)$ & 1 & & - & - \\
\hline Yes & $1(3)$ & $19(20)$ & $0.12(0.02-0.94)$ & $0.044^{* * * *}$ & - & - \\
\hline \multicolumn{7}{|c|}{ Disclosure of HIV status to close ones } \\
\hline No & $25(74)$ & $92(97)$ & 1 & & - & - \\
\hline Yes & $9(26)$ & $3(3)$ & $11.04(2.78-43.86)$ & $<0.001$ & - & - \\
\hline \multicolumn{7}{|c|}{ Persons who were told about HIV status } \\
\hline Friends & $1(11)$ & $2(67)$ & 1 & & - & - \\
\hline Siblings, parents & $8(89)$ & $1(33)$ & $16(0.67-383.01)$ & 0.087 & - & - \\
\hline \multicolumn{7}{|c|}{ Clinical follow up and immunovirological status } \\
\hline \multicolumn{7}{|l|}{ Followed } \\
\hline No & $2(6)$ & $4(4)$ & 1 & & - & - \\
\hline Yes & $32(94)$ & $91(96)$ & $0.7(0.12-4.03)$ & 0.690 & - & - \\
\hline \multicolumn{7}{|l|}{ Place of follow up } \\
\hline Private practice & $11(34)$ & $25(27)$ & 1 & & - & - \\
\hline Hospital & $21(66)$ & $66(73)$ & $0.82(0.35-1.93)$ & 0.660 & - & - \\
\hline \multicolumn{7}{|c|}{ Modalities of follow up } \\
\hline Irregular & $2(6)$ & $15(16)$ & 1 & & - & - \\
\hline Regular & $30(94)$ & $76(84)$ & $2.04(0.55-7.54)$ & 0.260 & & \\
\hline \multicolumn{7}{|c|}{ HIV related diseases during pregnancy } \\
\hline No & $29(85)$ & $92(97)$ & 1 & & 1 & \\
\hline Yes & $5(15)$ & $3(3)$ & $5.29(1.19-23.48)$ & 0.029 & $6.57(0.66-64.93)$ & 0.136 \\
\hline \multicolumn{7}{|c|}{ Number of prenatal visits } \\
\hline$\leq 6$ & $7(22)$ & $25(27)$ & 1 & & - & - \\
\hline$>6$ & $25(78)$ & $83(73)$ & $1.38(0.53-3.56)$ & 0.510 & - & - \\
\hline \multicolumn{7}{|c|}{ Viral load, CD4 measured } \\
\hline No & $13(38)$ & $17(18)$ & 1 & & - & - \\
\hline Yes & $21(62)$ & $78(82)$ & $0.35(0.15-0.84)$ & 0.018 & - & - \\
\hline
\end{tabular}

* Obtained using conditional logistic regression with indicator variables for non binary variables

* Low power $(29 \%)$

*** Low power $(28 \%)$

**** Low power $(30 \%)$

Table 1: Case and control description, bivariate and multivariate analysis*.

\section{Bivariate analysis}

Demographic and socioeconomic risk factors: Factors associated with HIV status disclosure were the existence of a steady job, having a private car for transportation, having informed the doctor, the desire of pregnancy and the use of condoms. On the other hand, when the partner was HIV-negative, it influenced negatively the HIV status disclosure. The partner change also influenced negatively the HIV status disclosure.
Factors without a significant effect: Health insurance was not significantly different between cases and controls. There was no significant difference regarding residence permits for foreign mothers. Transport duration, educational level, understanding of French language and the number of children at home were not significantly associated with the outcome. Partner change and multiple sexual partnerships were not significantly associated with the outcome. The number of pregnancies, the number of known HIV-positive 
pregnancies, breastfeeding (four women breastfed their babies), alcohol and tobacco use were not associated with the outcome.

Perceptions towards HIV and addictions: The negative representations of HIV had a positive influence on the disclosure of HIV status. Knowledge about HIV, using tobacco, alcohol or drugs (marijuana, crack, cocaine) were not significantly associated with the outcome.

Faiths and attitudes towards the HIV: The disclosure of the HIV status to other than the partner was significantly associated with the outcome. The proportion of women practicing religion was identical in cases and controls. The practice of religion had no influence on the HIV status disclosure.

\section{Multivariate analysis}

The saturated model included education level, mode of transport, profession, disclosure of HIV status to close ones, use of condoms, desired pregnancy, disclosure to the doctor, negative representations of HIV, partner's HIV status and HIV related diseases during pregnancy. The variables that independently predicted for HIV disclosure to the sex partner were the existence of a steady job, disclosure to the doctor, the negative representations of HIV, the partner's HIV status. The number of prenatal visits was not linked to the outcome.

\section{Discussion}

Non disclosure of this sexually transmitted infection is a challenging problem for health professionals. So much, there is a vast word literature on HIV disclosure [23-31], so much little is known about HIV disclosure among perinatal women [32-36]. Although the retrospective design and small sample size are weaknesses of the present study, to our knowledge, it is the only study that has studied the topic in this vulnerable group. Prevention of the mother to child transmission of HIV implies knowledge of the interaction of geographic, demographic, cultural, socioeconomic and sanitary factors but, with $70 \%$ of fathers unaware of the pregnant women's HIV status, the desire for pregnancy and a family may also lead to the risk of infecting the potential father. Interestingly, nationality, educational level or religion where not associated with differences in disclosure of the pregnant mother's HIV status. Housing conditions or the administrative situation were also not associated with differences in disclosure. However, as described by others $[15,32,34]$, having a job, possession of a personal vehicle, having discussed the desire for pregnancy with a physician, a desired pregnancy for the couple and condom use were factors associated with disclosure of the pregnant woman's HIV status to the father of her child. Having health insurance also seemed associated with greater disclosure. Negative representations of HIV (HIV as a curse), having a new partner and the fact that the father was HIV negative were independently risk factors for not disclosing the HIV status.

Although, it often reflects poverty and cause problems to conceal one's illness (treatments, prescriptions may reveal the disease...), living in someone else's home was not a risk factor for not disclosing the HIV status.

Foreign populations often have different representations of health and diseases. Religion and supernatural beliefs are often at the forefront. The first priority is daily survival and the search for local integration, and the struggle to obtain a residence permit and avoid expulsion. However, these variables did not evidently seem to relate to disclosure in pregnant women. This is at odds with the VESPA study, in the general HIV cohort that found that there were differences between nationalities in disclosure and condom use.
A regular follow up of HIV-infected patients is mandatory for the initiation of appropriate antiretroviral therapy and pregnancy follow up [37]. HIV representations in French Guiana are still very negative. Stigma and discrimination remain major obstacles to HIV disclosure [15-17,34]. Economic dependency makes the announcement of a woman's HIV status a gamble where she can be abandoned, without a home and without resources [15-17,38]. Delay to disclose the diagnosis adds a layer of lies to disclose to the father in addition to the diagnosis itself. Nearly $20 \%$ of infected persons living in a couple do not disclose their status to their partner $[14,39]$. Apparently, this figure is even higher in pregnant women. This is problematic for the follow up of women and their children after delivery, because of the potentially revealing questions of the child's father.

The promotion of HIV disclosure and the greater implication of the future father seem intuitive responses; however they could backfire and lead to pregnant women avoiding care altogether [40-41].

\section{Conclusion}

The present study showed, despite its shortcomings, the rarity of HIV disclosure and factors associated with it. Non-disclosure is a risk factor for treatment and follow up avoidance, and potential transmission of the virus to the father and the child. Knowing these factors may help in preventing loss to follow up and ensuring optimal care and treatment as prevention.

\section{References}

1. Nacher M, Vantilcke V, Huber F, El Guedj M, Vaz T, et al. (2009) Paralle evolutions of the growth rate of newly diagnosed HIV cases and the proportion of potentially infective patients in Cayenne French Guiana: should HAART be used to curb the epidemic? Public Health 123: 573-574.

2. Nacher M, Vantilcke V, Parriault MC, Van Melle A, Hanf M, et al. (2010) What is driving the HIV epidemic in French Guiana? Int J STD AIDS 21: 359-361.

3. Nacher M, Adenis A, Hanf M, Adriouch L, Vantilcke V, et al. (2009) Crack cocaine use increases the incidence of AIDS-defining events in French Guiana. AIDS 23: 2223-2226.

4. Nacher M, Adriouch L, Adenis A, Hanf M, Van Melle A, et al. (2011) Risk factors for delayed access to specialized care in French Guiana. Am J Trop Med Hyg 84: 806-807.

5. Nacher M, Adriouch L, Godard Sebillotte C, Hanf M, Vantilcke V, et al. (2010) Predictive factors and incidence of anxiety and depression in a cohort of HIV positive patients in French Guiana. AIDS Care 22: 1086-1092.

6. Nacher M, Vantilcke V, Huber F, El Guedj M, Vaz T, et al. (2009) Paralle evolutions of the growth rate of newly diagnosed HIV cases and the proportion of potentially infective patients in Cayenne French Guiana: should HAART be used to curb the epidemic? Public Health 123: 573-574.

7. Jolivet A, Cadot E, Florence S, Lesieur S, Lebas J, et al. (2012) Migrant health in French Guiana: are undocumented immigrants more vulnerable? BMC Public Health 12: 53

8. Nacher M, El Guedj M, Vaz T, Nasser V, Randrianjohany A, et al. (2005) Risk factors for late HIV diagnosis in French Guiana. AIDS 19: 727-729.

9. Nacher M, El Guedj M, Vaz T, Nasser V, Randrianjohany A, et al. (2006) Risk factors for follow-up interruption of HIV patients in French Guiana. Am J Trop Med Hyg 74: 915-917.

10. Halfen S, Fenies K, Ung B, Gremy I (2006) Les connaissances, attitudes, croyances et comportements face au $\mathrm{VIH} /$ sida aux Antilles et en Guyane en 2004. ORS Ile-de-France.

11. Tonwe-Gold B, Ekouevi DK, Bosse CA, Toure S, Koné M, et al. (2009) Implementing family-focused HIV care and treatment: the first 2 years experience of the mother-to-child transmission-plus program in Abidjan, Côte d'Ivoire. Trop Med Int Health 14: 204-212.

12. Makin JD, Forsyth BW, Visser MJ, Sikkema KJ, Neufeld S, et al. (2008) Factors affecting disclosure in South African HIV-positive pregnant women. AIDS Patient Care STDS 22: 907-916. 
Citation: Narcisse E, Matthieu H, Mathieu N (2012) Predictive Factors of HIV Status Disclosure to Sex Partner in Pregnant Women in Cayenne, French Guiana. Epidemiol 2:116. doi:10.4172/2161-1165.1000116

13. Visser MJ, Neufeld S, de Villiers A, Makin JD, Forsyth BW (2008) To tell or not to tell: South African women's disclosure of HIV status during pregnancy. AIDS Care 20: 1138-1145.

14. Kilewo C, Massawe A, Lyamuya E, Semali I, Kalokola F, et al. (2001) HIV counseling and testing of pregnant women in sub-Saharan Africa: experiences from a study on prevention of mother-to-child HIV-1 transmission in Dar es Salaam, Tanzania. J Acquir Immune Defic Syndr 28: 458-462.

15. Olagbuji BN, Ezeanochie MC, Agholor KN, Olagbuji YW, Ande AB, et al. (2011) J Obstet Gynaecol 31: 486-488.

16. Gari T, Habte D, Markos E (2010) HIV positive status disclosure among women attending art clinic at Hawassa University Referral Hospital, South Ethiopia. East Afr J Public Health 7: 87-91.

17. Brickley DB, Le Dung Hanh D, Nguyet LT, Mandel JS, Giang le T, et al. (2009) Community, family, and partner-related stigma experienced by pregnant and postpartum women with HIV in Ho Chi Minh City, Vietnam. AIDS Behav 13: 1197-1204.

18. Elenga N, Hanf M, Nacher M (2012) Predictive factors of antiretroviral treatment $<4$ weeks among HIV-infected pregnant women in Cayenne, French Guiana. AIDS Care 24: 46-53.

19. Masse V, Dray-Spira R, Spire B, Schmaus A, Lert F (2003) Vie de couple, vie sexuelle et pr vention chez les $\mathrm{h} t$ rosexuels vivant avec le $\mathrm{VIH}$-sida aux Antilles et en Guyane. R sultats de l'enqu te ANRS-Vespa. Bulletin Epidemiologique Hebdomadaire 46-47: 243-244.

20. Desgrées-du-Lou A, Brou H, Traore AT, Djohan G, Becquet R, et al. (2009) From prenatal HIV testing of the mother to prevention of sexual HIV transmission within the couple. Soc Sci Med 69: 892-899.

21. Brou H, Djohan G, Becquet R, Allou G, Ekouevi DK, et al. (2007) When do HIV-infected women disclose their HIV status to their male partner and why? A study in a PMTCT programme, Abidjan. PLoS Med 4: e342.

22. Pugliese P, Cuzin L, Enel P, Agher R, Alfandari S, et al. (2003) [NADIS 2000, development of an electronic medical record for patients infected by HIV, HBV and HCV]. Presse Med 32: 299-303.

23. Seid M, Wasie B, Admassu M (2012) Disclosure of HIV positive result to a sexual partner among adult clinical service users in Kemissie district, northeast Ethiopia. Afr J Reprod Health 16: 97-104.

24. Kouanda S, Yaméogo WM, Berthé A, Bila B, Bocoum Yaya FK, et al. (2012) [Self-disclosure of a HIV-positive serostatus: Factors favoring disclosure and consequences for persons living with HIVIAIDS in Burkina Faso]. Rev Epidemiol Sante Publique 60: 221-228.

25. Osinde MO, Kakaire O, Kaye DK (2012) Factors associated with disclosure of HIV serostatus to sexual partners of patients receiving HIV care in Kabale, Uganda. Int J Gynaecol Obstet 118: 61-64.

26. Caldwell DH, Jan G (2012) Computerized Assessment Facilitates Disclosure of Sensitive HIV Risk Behaviors among African Americans Entering Substance Abuse Treatment. Am J Drug Alcohol Abuse 38: 365-369.
27. St De Lore J, Thiede H, Cheadle A, Goldbaum G, Carey JW, et al. (2012) HIV disclosure and subsequent sexual behaviors among men who have sex with men who meet online. J Homosex 59: 592-609.

28. Hosseinzadeh H, Hossain SZ, Bazargan-Hejazi S (2012) Perceived stigma and social risk of HIV testing and disclosure among Iranian-Australians living in the Sydney metropolitan area. Sex Health 9: 171-177.

29. Maiorana A, Koester KA, Myers JJ, Lloyd KC, Shade SB, et al. (2012) Helping patients talk about HIV: inclusion of messages on disclosure in prevention with positives interventions in clinical settings. AIDS Educ Prev 24: 179-192.

30. Nachega JB, Morroni C, Zuniga JM, Sherer R, Beyrer C, et al. (2012) HIV Related Stigma, Isolation, Discrimination, and Serostatus Disclosure: A Global Survey of 2035 HIV-Infected Adults. J Int Assoc Physicians AIDS Care (Chic) 11: $172-178$.

31. Gaskins SW, Foster Payne P, Sowell RL, Gardner A, Lewis TL, et al. (2012) Making Decisions: The Process of HIV Disclosure for Rural African American Men. Am J Mens Health.

32. Ross R, Stidham AW, Drew BL (2012) HIV disclosure by perinatal women in Thailand. Arch Psychiatr Nurs 26: 232-239.

33. Mucheto P, Chadambuka A, Shambira G, Tshimanga M, Gombe N, et al (2011) Determinants of nondisclosure of HIV status among women attending the prevention of mother to child transmission programme, Makonde district, Zimbabwe, 2009. Pan Afr Med J 8: 51.

34. Anglewicz P, Chintsanya J (2011) Disclosure of HIV status between spouses in rural Malawi. AIDS Care 23: 998-1005.

35. Suhadev M, Mahadevan U, Dilip M, Suryanarayanan D, Sikhamani R, et al (2011) Percentages, Process, and Patterns of HIV Disclosure Among the Spouses of HIV-Infected Men in South India. J Int Assoc Physicians AIDS Care (Chic) 10: 26-29

36. Vu L, Andrinopoulos K, Mathews C, Chopra M, Kendall C, et al. (2012) Disclosure of HIV status to sex partners among HIV-infected men and women in Cape Town, South Africa. AIDS Behav 16: 132-138.

37. Sobesky M, Zoccarato AM, Magnien C, Rocca Serra P, Bissuel F, et al. (2003) [The HIV infection in pregnant women in French Guiana]. Gynecol Obstet Fertil 31: 343-349.

38. Ssali SN, Atuyambe L, Tumwine C, Segujia E, Nekesa N, et al. (2010) Reason for disclosure of HIV status by people living with HIVIAIDS and in HIV care in Uganda: an exploratory study. AIDS Patient Care STDS 24: 675-681.

39. Painter TM, Diaby KL, Matia DM, Lin LS, Sibailly TS, et al. (2005) Sociodemographic factors associated with participation by HIV-1-positive pregnant women in an intervention to prevent mother-to-child transmission of HIV in Cote d'Ivoire. Int J STD AIDS 16: 237-242.

40. Obermeyer CM, Baijal P, Pegurri E (2011) Facilitating HIV disclosure across diverse settings: a review. Am J Public Health 101: 1011-1023.

41. Smith R, Rossetto K, Peterson BL (2008) A meta-analysis of disclosure of one's HIV-positive status, stigma and social support. AIDS Care 20: 1266-1275.

Submit your next manuscript and get advantages of OMICS Group submissions

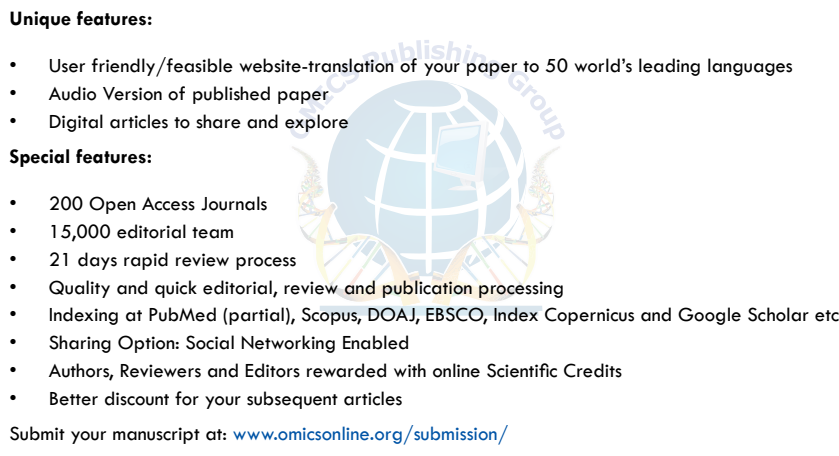

